\title{
Determining the Correlation Between Specific Characters of Bucovina Shepherd Dogs
}

\author{
Constantin PASCAL ${ }^{1}$, Constantin Viorel GASPAR ${ }^{2)}$ \\ 1)Faculty of Animal Sciences, University of Agricultural Sciences and Veterinary Medicine, Iasi, 3 Mihail \\ Sadoveanu Alley, 700490 Iaşi, Romania \\ ${ }^{2)}$ Romanian Bucovina Sheperd Dog Club \\ *Corresponding author, e-mail: pascalc@uaiasi.ro
}

Bulletin UASVM Animal Science and Biotechnologies 72(2) / 2015

Print ISSN 1843-5262; Electronic ISSN 1843-536X

DOI:10.15835/buasvmcn-asb:11332

\begin{abstract}
Forming sheepdog breeds has had primarily economic and utility objectives and is the direct result of the influence of natural factors, or of reproductive isolation, a process which resulted in natural breeds characterized by genetic, phenotypical and behavioural uniformity. The current economic importance of breeding Bucovina Shepherd dogs is very well highlighted by the fact that in the area of origin there appeared a number of kennels, in which selection programs and routed mating are applied in order to increase the quality of genetic material and to enhance the skills of this dog. From this point of view, we analyse the existence of genetic correlations between certain morphometric characteristics in Bucovina Shepherd dogs, and carry out a comprehensive study on some elements that make the difference among the four breeds of shepherd dogs raised in Romania. These endeavours are part of current concerns addressed in animal husbandry. Biological material subject to investigation was represented by the canine population belonging to the Bucovina Shepherd Dog breed, raised in the North-Eastern part of Romania. As a result of statistical data processing and interpretation, it was established that for most attributes, in the couples analysed, the correlation coefficient exceeds 0.400 which means, in general, that the analysed characteristics are well correlated. However, there are also weakly correlated characteristics $(\mathrm{r}<0.2)$ as is the case of dorsum height and hip height. Instead, the correlation between the height of the base of the tail and back height was positive and intense $(r=0.98)$, which means that the selection applied for one of these two characteristics leads to the improvement of the other characteristic. Also, as a general conclusion of the study, the results could be applied in the improvement of this sheepdog population because the correlation coefficient values recorded between the main characteristics analysed have been statistically distinctly significant $(\mathrm{p}<0.01 \%)$.
\end{abstract}

Keywords: Shepherd dogs, correlations, Bucovina

\section{INTRODUCTION}

Considered man's best friends, thanks to their qualities, attachment to their masters and the myriad of activities they help with, dogs have earned a special status within everyday human life. Since the early stages of dog domestication, people have been attracted by them, creating a close relationship which has been strengthened and perpetuated over time. Being a species endowed with many qualities, the dog is often used for company, to help with different activities and even do some work without expecting anything in return. It is useful to human activities, to guard their flocks, the households, in the police and army, assisting people with disabilities, in transporting equipment, giving us total attachment and loyalty at the same time (Gaşpar C.V., 1999; 2008 a; 2008b; 2014;).

Over time, man has always sought to shape the dog's character in its own interest, and currently there are many dog breeds that have developed some features in order to achieve a specific utility. Such new breeds have appeared in addition to the dedicated guard dog breeds, hunting or 
companion breeds, and today these can be used also in guarding the flocks or cattle herds.

The objectives of the present research are specific to modern cynology. Based on scientific data and results, we try to highlight the role and importance of genetic correlations between some morphometric characteristics in the formation and improvement of a new local Sheepdog breed, namely the Bucovina Shepherd Dog, as well as to point out the role and contribution of this breed to guard and protect herds.

In the animal's body, it has been found that many phenotypic characteristics are developed in conjunction one with another. The fact that changing the value of one characteristic causes the amendment of the value of another characteristic in the same body means that these two characteristics co-vary (Vintilă, 1988). The sense and the size of the changes occurring at the same time in the two correlative characteristics can be appreciated by means of the coefficient of correlation and regression. Correlations between different characteristics can be genetic $\left(r_{G}\right)$ or caused by the environment $\left(\mathrm{r}_{\mathrm{E}}\right)$, which together give the phenotypic or total correlation $\left(r_{p}\right)$.

Genetic correlations are caused by the pleiotropic action of some additive genes, or by the linkage between different loci. As concerns the size and sense of the correlation coefficients, they have a special importance because they allow the improvement of a particular characteristic if the selection is made depending on the other characteristic, and so, the number of the objectives in selection is reduced (Pipernea, 1974).

\section{MATERIALS AND METHODS}

The biological material subjected to investigation was represented by canine populations belonging to the Bucovina Shepherd Dog breed from kennels and households located in the North-Eastern part of Romania. In order to obtain relevant statistical data, the analysed canine population was represented by 56 females between the ages of 3 and 7 years. All females subjected to the research are in the records of the Bucovina National Club Breeders and Owners of Thoroughbred Dogs Bucovina Shepherd Dog. Also, the whole population was recorded in the Herd Book of the Bucovina Shepherd Dog breed.

Pearson's coefficient correlations were calculated between different parts of the body and data were statistically analysed using REML
Statistical Programme. Making such determinations aimed to reveal the relationship between different measurements, particularly between those subjected to the selection, because the correlations show not only a uniform distribution, but also specify a strictly linear relation between two variables ( $\mathrm{x}$ and $\mathrm{y}$ ).

\section{RESULTS AND DISCUSSIONS}

In the canine selection work it is absolutely necessary to know the correlation coefficients between different morphological characteristics, because the effect of the selection can be increased with their help.

If the genetic determinism of two characteristics of great interest involves the same genes (pleiotropic effect), i.e. these traits are genetically correlated, the selection for both characteristics is not absolutely necessary, because a positive change can be achieved by making the selection by the other character.

The values of the correlation coefficients between the main couples of characteristics surveyed during the research are presented in table 1. These values show both the intensity of the link between the two correlative characteristics, and the sense (positive or negative) of the correlation.

The data obtained in the study reflect the existence of positive and intense correlations between different groups of characteristics and also situations in which negative correlations are recorded between different pairs of traits.

Table 1 presents the average values determined between the body weight and height measured at the different anatomic parts of the Bucovina Shepherd Dog breed. The fact that for most couples of attributes analysed Pearson's correlation coefficients exceed 0.400 means that these characteristics are generally strongly correlated.

Correlation coefficients between body weight and body height at the withers, spine and shoulders are positive and intense, and statistically significant $(\mathrm{p}<0.05 ; \mathrm{p}<0.01)$. Some recent studies carried out by Dronca et al., 2015 on a batch of 23 females aged between 3 and 6 years show that in the Romanian Mioritic females Shepherd dogs, the correlation between height at the withers and body length is positive and intense $(r=0,571$; $p$ $<0,01$ ).

However, there are also weakly correlated characteristics $(r<0.2)$ as is the case of height at the 
Tab.1. The correlation between weight and height at different anatomical parts of the body for Shepherd Dog of Bucovina breed $(n=56)$

\begin{tabular}{|c|c|c|c|c|c|c|c|c|}
\hline \multicolumn{2}{|c|}{$\begin{array}{c}\text { Correlations between } \\
\text { characters }\end{array}$} & \multirow{2}{*}{$\begin{array}{c}\begin{array}{c}\text { Body weight } \\
(\mathrm{kg})\end{array} \\
1\end{array}$} & \multirow{2}{*}{$\begin{array}{c}\begin{array}{c}\text { Height at } \\
\text { withers } \\
(\mathrm{cm})\end{array} \\
0.792^{* *}\end{array}$} & \multirow{2}{*}{$\begin{array}{c}\begin{array}{c}\text { Height at } \\
\text { spine } \\
(\mathrm{cm})\end{array} \\
0.773^{* *}\end{array}$} & \multirow{2}{*}{$\begin{array}{c}\begin{array}{c}\text { Height at } \\
\text { shoulder } \\
(\mathrm{cm})\end{array} \\
0.714^{* *}\end{array}$} & \multirow{2}{*}{$\begin{array}{c}\begin{array}{c}\text { Height of } \\
\text { base of the } \\
\text { tail }(\mathrm{cm})\end{array} \\
0.732^{* *}\end{array}$} & \multirow{2}{*}{$\begin{array}{c}\begin{array}{c}\text { Elevation at } \\
\text { hock }(\mathrm{cm})\end{array} \\
0.381^{* *}\end{array}$} & \multirow{2}{*}{$\begin{array}{c}\begin{array}{c}\text { Height at hip } \\
(\mathrm{cm})\end{array} \\
0.288^{*}\end{array}$} \\
\hline Body weight & $\begin{array}{c}\text { Pearson } \\
\text { Correlation }\end{array}$ & & & & & & & \\
\hline & Sig. (2-tailed) & - & 0.000 & 0.000 & 0.000 & 0.000 & 0.004 & 0.031 \\
\hline \multirow{2}{*}{$\begin{array}{l}\text { Height at withers } \\
\qquad(\mathrm{cm})\end{array}$} & $\begin{array}{c}\text { Pearson } \\
\text { Correlation }\end{array}$ & $0.792^{* *}$ & 1 & $0.933^{* *}$ & $0.912^{* *}$ & $0.899^{* *}$ & 0.180 & 0.121 \\
\hline & Sig. (2-tailed) & 0.000 & - & 0.000 & 0.000 & 0.000 & 0.186 & 0.375 \\
\hline \multirow{2}{*}{$\begin{array}{l}\text { Height at spine } \\
\qquad(\mathrm{cm})\end{array}$} & $\begin{array}{c}\text { Pearson } \\
\text { Correlation }\end{array}$ & $0.773^{* *}$ & $.933^{* *}$ & 1 & $0.937^{* *}$ & $0.924^{* *}$ & $0.322^{*}$ & 0.109 \\
\hline & Sig. (2-tailed) & 0.000 & 0.000 & - & 0.000 & 0.000 & 0.016 & 0.423 \\
\hline \multirow{2}{*}{$\begin{array}{c}\text { Height at } \\
\text { shoulder }(\mathrm{cm})\end{array}$} & $\begin{array}{c}\text { Pearson } \\
\text { Correlation } \\
\end{array}$ & $0.714^{* *}$ & $0.912^{* *}$ & $0.937^{* *}$ & 1 & $0.980^{* *}$ & 0.169 & 0.176 \\
\hline & Sig. (2-tailed) & 0.000 & 0.000 & 0.000 & - & 0.000 & 0.214 & 0.193 \\
\hline \multirow{2}{*}{$\begin{array}{l}\text { Height at base of } \\
\text { the tail }(\mathrm{cm})\end{array}$} & $\begin{array}{c}\text { Pearson } \\
\text { Correlation }\end{array}$ & $0.732^{* *}$ & $0.899^{* *}$ & $0.924^{* *}$ & $0.980^{* *}$ & 1 & 0.221 & 0.155 \\
\hline & Sig. (2-tailed) & 0.000 & 0.000 & 0.000 & 0.000 & - & 0.102 & 0.254 \\
\hline \multirow{2}{*}{$\begin{array}{l}\text { Elevation at the } \\
\text { hock }(\mathrm{cm})\end{array}$} & $\begin{array}{c}\text { Pearson } \\
\text { Correlation }\end{array}$ & $0.381^{* *}$ & 0.180 & $0.322^{*}$ & 0.169 & 0.221 & 1 & -0.023 \\
\hline & Sig. (2-tailed) & 0.004 & 0.186 & 0.016 & 0.214 & 0.102 & - & 0.865 \\
\hline \multirow[t]{2}{*}{ Height at hip (cm) } & $\begin{array}{c}\text { Pearson } \\
\text { Correlation } \\
\end{array}$ & $0.288^{*}$ & 0.121 & 0.109 & 0.176 & 0.155 & -0.023 & 1 \\
\hline & Sig. (2-tailed) & 0.031 & 0.375 & 0.423 & 0.193 & 0.254 & 0.865 & - \\
\hline
\end{tabular}

**. Correlation is distinctly significant at the 0.01 level (2-tailed).

*. Correlation is significant at the 0.05 level (2-tailed).

hips and other body parts (height at the withers, spine, base of the tail, and elevation of the hock). On the other hand, the correlation between height at the base of the tail and height at the shoulders ( $\mathrm{r}=0.980 ; \mathrm{p}<0.01$ ) is strong and positive, and statistically distinctly significant, which means that whenever the selection is done for one of these two characteristics, this will impact the improvement of the pair's characteristic.

Between most of the analysed characteristics in Romanian Bucovina Shepherd dogs we established statistically significant correlation coefficients at the $1 \%$ threshold. There are, however, exceptions such as between the height at the base of the tail and the height at the hip, where the correlations are statistically insignificant $(\mathrm{p}>0.05)$. Moreover, a negative correlation $(\mathrm{r}=-0.023)$ was established between the height at the hock and height at the hip.
Statistical processing of data highlights the fact that body weight positively and intensely correlates with the following characteristics: withers height, dorsum height, shoulder height and height at the base of the tail. Although, in the couple weight-height at the hock, the correlation coefficient has a medium value, this correlation is statistically significant at the $1 \%$ threshold. In value, correlation coefficients can vary from 0 to 1 or from 0 to -1 . In this sense, the determined values indicate the level at which you place the correlation between two characteristics. When the value of the correlation coefficient is placed very close to 1 , it means that between those two characteristics considered, there is a very strong and positive correlation, which is also known as functional correlation. When the correlation coefficient has values from 0 to -1 , then between the two characteristics there is a negative correlation. 
Tab. 2. Correlation between body weight and various sizes of length, width and perimeter, determined at Romanian Shepherd dogs of Bucovina $(n=56)$

\begin{tabular}{|c|c|c|c|c|c|c|c|c|c|c|c|c|}
\hline Corr & elation & $\begin{array}{l}\text { Weight } \\
\text { (kg) }\end{array}$ & $\begin{array}{l}\text { Chest } \\
\text { depth } \\
(\mathrm{cm})\end{array}$ & $\begin{array}{l}\text { Chest } \\
\text { spread } \\
(\mathrm{cm})\end{array}$ & $\begin{array}{l}\text { Chest } \\
\text { width } \\
(\mathrm{cm})\end{array}$ & $\begin{array}{l}\text { Width } \\
\text { at loin } \\
(\mathrm{cm})\end{array}$ & $\begin{array}{c}\text { Width at } \\
\text { shoulder } \\
(\mathrm{cm})\end{array}$ & $\begin{array}{l}\text { Length of } \\
\text { the spine } \\
(\mathrm{cm})\end{array}$ & $\begin{array}{l}\text { Length } \\
\text { of croup } \\
(\mathrm{cm})\end{array}$ & $\begin{array}{l}\text { Torso } \\
\text { length } \\
(\mathrm{cm})\end{array}$ & $\begin{array}{c}\text { Thoracic } \\
\text { perimet. } \\
(\mathrm{cm})\end{array}$ & $\begin{array}{c}\text { Whistle } \\
\text { Perimet. } \\
\text { (cm) }\end{array}$ \\
\hline \multirow{2}{*}{$\begin{array}{l}\text { Body } \\
\text { weight } \\
\text { (kg) }\end{array}$} & $\begin{array}{c}\text { Pearson } \\
\text { Correlation }\end{array}$ & 1 & $0.287^{*}$ & 0.135 & $0.328^{*}$ & 0.225 & 0.102 & 0.150 & -0.124 & $0.554^{* *}$ & $0.544^{* *}$ & $0.466^{* *}$ \\
\hline & $\begin{array}{c}\text { Sig. } \\
\text { (2-tailed) }\end{array}$ & - & 0.032 & 0.320 & 0.014 & .0095 & 0.454 & 0.271 & 0.363 & 0.000 & 0.000 & 0.000 \\
\hline \multirow{2}{*}{$\begin{array}{l}\text { Chest } \\
\text { depth } \\
(\mathrm{cm})\end{array}$} & $\begin{array}{c}\text { Pearson } \\
\text { Correlation }\end{array}$ & $0.287^{*}$ & 1 & $0.521^{* *}$ & 0.214 & 0.231 & 0.247 & 0.000 & -0.220 & $0.343^{* *}$ & $0.621^{* *}$ & 0.073 \\
\hline & $\begin{array}{c}\text { Sig. } \\
\text { (2-tailed) }\end{array}$ & 0.032 & - & 0.000 & 0.113 & 0.087 & 0.067 & 0.997 & 0.103 & 0.010 & 0.000 & 0.593 \\
\hline \multirow{2}{*}{$\begin{array}{l}\text { Chest } \\
\text { spread } \\
(\mathrm{cm})\end{array}$} & $\begin{array}{c}\text { Pearson } \\
\text { Correlation } \\
\end{array}$ & 0.135 & $0.521^{* *}$ & 1 & 0.158 & 0.132 & $0.277^{*}$ & 0.163 & -0.018 & $0.285^{*}$ & $0.376^{* *}$ & 0.072 \\
\hline & $\begin{array}{c}\text { Sig. } \\
\text { (2-tailed) }\end{array}$ & 0.320 & 0.000 & - & 0.245 & 0.334 & 0.039 & 0.231 & 0.893 & 0.033 & 0.004 & 0.600 \\
\hline \multirow{2}{*}{$\begin{array}{l}\text { Chest } \\
\text { width } \\
(\mathrm{cm})\end{array}$} & $\begin{array}{c}\text { Pearson } \\
\text { Correlation } \\
\end{array}$ & $0.328^{*}$ & .214 & .158 & 1 & -0.072 & 0.168 & 0.139 & 0.101 & 0.061 & 0.221 & 0.083 \\
\hline & $\begin{array}{c}\text { Sig. } \\
\text { (2-tailed) }\end{array}$ & 0.014 & 0.113 & 0.245 & - & 0.596 & 0.217 & 0.306 & 0.458 & 0.655 & 0.101 & 0.544 \\
\hline \multirow{2}{*}{$\begin{array}{l}\text { Width at } \\
\text { loin }(\mathrm{cm})\end{array}$} & $\begin{array}{c}\text { Pearson } \\
\text { Correlation } \\
\end{array}$ & 0.225 & .231 & 0.132 & -0.072 & 1 & 0.147 & 0.062 & -0.040 & $0.292^{*}$ & 0.167 & 0.161 \\
\hline & $\begin{array}{c}\text { Sig. } \\
\text { (2-tailed) }\end{array}$ & 0.095 & 0.087 & 0.334 & 0.596 & - & 0.279 & 0.650 & 0.771 & 0.029 & 0.220 & 0.237 \\
\hline \multirow{2}{*}{$\begin{array}{c}\text { Width at } \\
\text { shoulder } \\
(\mathrm{cm})\end{array}$} & $\begin{array}{c}\text { Pearson } \\
\text { Correlation } \\
\end{array}$ & 0.102 & 0.247 & $0.277^{*}$ & 0.168 & 0.147 & 1 & $0.293^{*}$ & 0.108 & 0.216 & $0.276^{*}$ & 0.178 \\
\hline & $\begin{array}{c}\text { Sig. } \\
\text { (2-tailed) }\end{array}$ & 0.454 & 0.067 & 0.039 & 0.217 & 0.279 & - & 0.028 & 0.430 & 0.109 & 0.040 & 0.188 \\
\hline \multirow{2}{*}{$\begin{array}{l}\text { Length of } \\
\text { the spine } \\
\text { (cm) }\end{array}$} & $\begin{array}{c}\text { Pearson } \\
\text { Correlation }\end{array}$ & 0.150 & 0.000 & 0.163 & 0.139 & 0.062 & $0.293^{*}$ & 1 & 0.041 & 0.124 & 0.087 & $0.301^{*}$ \\
\hline & $\begin{array}{c}\text { Sig. } \\
\text { (2-tailed) }\end{array}$ & 0.271 & 0.997 & 0.231 & 0.306 & 0.650 & 0.028 & - & 0.762 & 0.362 & 0.524 & 0.024 \\
\hline \multirow{2}{*}{$\begin{array}{l}\text { Length } \\
\text { of croup } \\
(\mathrm{cm})\end{array}$} & $\begin{array}{c}\text { Pearson } \\
\text { Correlation }\end{array}$ & -0.124 & -0.220 & -0.018 & 0.101 & -0.040 & 0.108 & 0.041 & 1 & $-0.392^{* *}$ & -0.236 & -0.201 \\
\hline & $\begin{array}{c}\text { Sig. } \\
\text { (2-tailed) }\end{array}$ & 0.363 & 0.103 & 0.893 & 0.458 & 0.771 & 0.430 & 0.762 & - & 0.003 & .080 & .138 \\
\hline \multirow{2}{*}{$\begin{array}{l}\text { Torso } \\
\text { length } \\
(\mathrm{cm})\end{array}$} & $\begin{array}{c}\text { Torso } \\
\text { length }(\mathrm{cm})\end{array}$ & $0.554^{* *}$ & $0.343^{* *}$ & $0.285^{*}$ & 0.061 & $0.292^{*}$ & 0.216 & 0.124 & $-0.392^{* *}$ & 1 & $0.442^{* *}$ & $0.462^{* *}$ \\
\hline & $\begin{array}{c}\text { Sig. } \\
\text { (2-tailed) }\end{array}$ & 0.000 & 0.010 & 0.033 & 0.655 & 0.029 & 0.109 & 0.362 & 0.003 & - & 0.001 & .000 \\
\hline \multirow{2}{*}{$\begin{array}{c}\text { Thoracic } \\
\text { perimeter } \\
(\mathrm{cm})\end{array}$} & $\begin{array}{c}\text { Pearson } \\
\text { Correlation }\end{array}$ & $0.544^{* *}$ & $0.621^{* *}$ & $0.376^{* *}$ & 0.221 & 0.167 & $0.276^{*}$ & 0.087 & -0.236 & $0.442^{* *}$ & 1 & $0.464^{* *}$ \\
\hline & $\begin{array}{c}\text { Sig. } \\
\text { (2-tailed) }\end{array}$ & 0.000 & 0.000 & 0.004 & 0.101 & 0.220 & 0.040 & 0.524 & 0.080 & 0.001 & - & .000 \\
\hline \multirow{2}{*}{$\begin{array}{l}\text { Whistle } \\
\text { perimete } \\
(\mathrm{cm})\end{array}$} & $\begin{array}{c}\text { Pearson } \\
\text { Correlation } \\
\end{array}$ & $0.466^{* *}$ & 0.073 & 0.072 & 0.083 & 0.161 & 0.178 & $0.301^{*}$ & -0.201 & $0.462^{* *}$ & $0.464^{* *}$ & 1 \\
\hline & $\begin{array}{c}\text { Sig. } \\
\text { (2-tailed) }\end{array}$ & 0.000 & 0.593 & 0.600 & 0.544 & 0.237 & 0.188 & 0.024 & 0.138 & .000 & .000 & - \\
\hline
\end{tabular}

**. Correlation is distinctly significant at the 0.01 level (2-tailed).

*. Correlation is significant at the 0.05 level (2-tailed). 
The height at the shoulder correlates intensely (0.714-0.980) with the body weight, with height at withers, with height at the spine and with the height of the base of the tail, and correlates weakly with hip height and height at the hock.

Withers height is in a strong correlation with live body weight, with height at shoulder, with dorsum height, with height at the base of the tail, and in a weak but significant correlation with height at the hock and height at the hip.

Height at the base of the tail is strongly correlated with live body weight, with height at the spine, with height of the withers, with height at the shoulder, and in a weak correlation with height at the hock and height at the hip.

In Table 2 are summarized results of correlation coefficients determined between the body weight of the adults and certain body measurements such are: the length, width and perimeter.

Pearson correlation has a high degree of statistical significance in the couplechest perimeter and whistle perimeter, also between body length and the depth of the chest, and between the live body weight and whistle perimeter.

\section{CONCLUSION}

1. Correlations between body weight determined at different ages and body height at the withers, at the dorsum, at the base of the tail and at rump are positive and strong $(\mathrm{p}<0.01)$.

2. Live body weight is also positively correlated, but just statistically significant $(\mathrm{p}<0.05)$, with the body height at the hip.

3. Body height at withers on Bucovina shepherd dog breed is positively correlated and with a high degree of statistical significance at $p<0.01$ with height at the spine, rump and the base of the tail.
4. Pearson's correlation coefficient has a high degree of statistical significance in the case of several couples of quality characteristics, such and chest perimeter and whistle perimeter, also between body length and the depth of the chest and between the live weight and the perimeter of the whistle.

5. Knowing these correlations can serve to define the characteristics which can be included in the amelioration programme of the Romanian Bucovina Shepherd dog breed.

\section{REFERENCES}

1. Dronca D, Pacala N, Bencsik I, Oroian T, Cighi V, Popa R, Cean A, Marcu A, Dronca A. (2015) Researches Regarding the Existence of Phenotypic Correlations between Different Body Measurements in Females from Romanian Mioritic Shepherd Dog. Bulletin USAMVCN, Animal Sciences and Biotechnologies 72/1, p 89-90.

2. Gaşpar CV. (2014) Research regarding formation and evolution of Bucovina Romanian shepherd dog in correlation with sheep rearing. Doctoral Thesis. USAMV Iasi-Romania

3. Gaşpar CV, Gaşpar C, Gaşpar G. (2008a ) The Standard of the Bucovina Romanian Shepherd dog breed, Lucr. S,t. Seria Medicină Veterinară Iași, 51(10): 755-760.

4. Gaşpar CV, Gaşpar C, Gaşpar G. (2008b) The becoming of the Bucovina Romanian Shepherd dog breed, Lucr. St. Seria Medicină Veterinară Iași, 51 (10): 761-768

5. Gaşpar CV. (1999) The Romanian and the Carpathian Romanian shepherd dog. Monitoring Institut for rare breed and seeds in Europa. Swiss Agency for Environment Forest and Landscape, the Margase and Rudolf Gsell Fondation Basel, Elveția. p. 63-64.

6. Pipernea N. (1974) Improved genetic structure of animal populations, Ed. Ceres, București, Romania

7. Vintilă I. (1988). Bases of genetics amelioration of the domestic animal populations. Ed. Facla, Timişoara, Romania 